\author{
Anna ŚCIĄŻKO ${ }^{1,3}$ \\ Yosuke KOMATSU ${ }^{3}$ \\ Grzegorz BRUS ${ }^{2}$ \\ Shinji KIMIJIMA ${ }^{3}$ \\ Janusz S. SZMYD ${ }^{2}$
}

\title{
ANALIZA PROCESU REFORMINGU METANU PARĄ WODNĄ PRZY POMOCY UOGÓLNIONEJ METODY NAJMNIEJSZYCH KWADRATÓW
}

\begin{abstract}
Matematyczny model zjawiska fizycznego obarczony jest niepewnością, wynikającą z niedokładności pomiarów eksperymentalnych, wartości przyjętych parametrów oraz założonych uproszczeń modelowych. Artykuł przedstawia eksperymentalną oraz numeryczną analizę procesu parowego reforming metanu za pomocą Uogólnionej Metody Najmniejszych Kwadratów (GLS). Opublikowane dotychczas równania kinetyki procesu reformingu różnią się znacznie między sobą oraz nie zawierają analizy niepewności przedstawionych rezultatów. Algorytm GLS pozwala na wyznaczenia najbardziej prawdopodobnych wartości empirycznych parametrów definiujących szybkość reakcji reformingu oraz umożliwia obiektywną weryfikację przygotowanego modelu matematycznego. Analiza numeryczna została przeprowadzona w oparciu o badania eksperymentalne $\mathrm{z}$ wykorzystaniem $0.3 \mathrm{~g}$ próbki katalizatora Ni/YSZ 60:40\%v. Pokazano, że metoda GLS zapewnia poprawę dokładności zmiennych mierzonych oraz pozwala na wyznaczenie najbardziej prawdopodobnych wartości niewiadomych oraz niepewności charakteryzujących otrzymane wyniki.
\end{abstract}

Słowa kluczowe: katalizator Ni/YSZ, reforming parowy metanu, analiza błędów pomiarowych

\section{Wstęp}

W klasycznym podejściu do modelowania numerycznego, uproszczenia i niepewność modelu, wynikające z niepewności pomiarów eksperymentalnych, założonych wartości parametrów fizykochemicznych czy uproszczeń modelowych, są pomijane bądź nie są dyskutowane w wystarczającym stopniu. Bada-

\footnotetext{
${ }^{1}$ Autor do korespondencji/corresponding author: Anna Ściążko, Akademia Górniczo-Hutnicza w Krakowie, al. Mickiewicza 30, 30-059 Kraków, e-mail: sciazko@agh.edu.pl

${ }^{2}$ Akademia Górniczo-Hutnicza w Krakowie, al. Mickiewicza 30, 30-059 Kraków

${ }^{3}$ Shibaura Institute of Technology, Saitama, Japan
} 
nia dotyczące kinetyki procesu reformingu metanu można znaleźć w wielu opracowaniach [1,2,4-6], jednak opisy reakcji znacznie odbiegają od siebie. Ponadto, przedstawione rezultaty nie zawierają analizy niepewności uzyskanych wyników. W niemniejszej pracy przedstawiono eksperymentalną oraz numeryczną analizę procesu parowego reforming metanu za pomocą Uogólnionej Metody Najmniejszych Kwadratów (GLS), mającą na celu ocenę wybranych matematycznych modeli omawianego procesu. Metoda GLS zakłada wykorzystanie wszystkich zebranych wyników pomiarów bezpośrednio w modelu, co prowadzi do utworzenia nadokreślonego układu równań modelowych. Układ taki posiada większą liczbę równań niż niewiadomych, oraz ze względu na niepewności pomiarowe, staje się układem sprzecznym. Jak pokazano w [6] algorytm GLS pozwala na wyznaczenia najbardziej prawdopodobnych wartości niewiadomych parametrów definiujących szybkość reakcji reformingu: wspó1czynników rzędu reakcji i energii aktywacji. Oprócz powyższych korzyści, proponowana metoda, dzięki obliczeniu macierzy kowariancji rezultatów, umożliwia walidację przygotowanych modeli procesu oraz obiektywny, z matematycznego punktu widzenia, wybór najdokładniejszego z nich [7].

Analiza numeryczna procesu reformingu parowego metanu została przeprowadzona w oparciu o badania eksperymentalne $\mathrm{z}$ wykorzystaniem katalizatora $\mathrm{Ni} / \mathrm{YSZ}$, będącego popularnym materiałem dla wysokotemperaturowych ogniw paliwowych SOFC [2]. Reforming metanu jest rozważany w kontekście możliwego zastosowania w ogniwach SOFC w ramach wewnętrznego połączenia pośredniego lub reakcji zachodzącej bezpośrednio na anodzie. Zaprojektowanie i optymalizacja modelu układu przygotowania paliwa wymaga szczegółowej wiedzy na temat procesu reformingu [3].

W wykorzystanych modelach reformingu zaimplementowano nie tylko równania definiujące szybkość procesu, ale wprowadzono także równania wymuszające spełnienie podstawowych praw fizycznych. Zostało pokazane, że ich wprowadzenie znacznie poprawia jakość uzyskanych rezultatów. Metoda GLS została wykorzystana do wyznaczenia parametrów szybkości reformingu oraz obiektywnej walidacji przygotowanych matematycznych modeli procesu.

\subsection{Reforming parowy metanu}

Reakcjami chemicznymi dominującymi w rozważanym procesie są reforming metanu: $\mathrm{CH}_{4}+\mathrm{H}_{2} \mathrm{O} \leftrightarrow 3 \mathrm{H}_{2}+\mathrm{CO}$ oraz reakcja pary wodnej $\mathrm{z}$ tlenkiem węgla: $\mathrm{CO}+\mathrm{H}_{2} \mathrm{O} \leftrightarrow \mathrm{H}_{2}+\mathrm{CO}_{2}$ [5]. Druga $\mathrm{z}$ reakcji jest reakcją słabo egzotermiczną oraz szybką - zakłada się, że spełnia ona równanie równowagi [1]. Szybkość procesu jest determinowana przez kinetykę procesu reformingu:

$$
R_{s t}=w_{c a t} A \exp \left(-\frac{E}{R T}\right) p_{\mathrm{CH}_{4}}^{a} p_{\mathrm{H}_{2} \mathrm{O}}^{b}
$$


gdzie $R_{s t}$ - szybkość reakcji $\left[\mathrm{mol} \cdot \mathrm{s}^{-1} \cdot \mathrm{m}^{-3}\right], p$ - ciśnienie parcjalne [atm], $R=8.3145$ - uniwersalna stała gazowa $\left[\mathrm{J} \cdot \mathrm{mol}^{-1} \cdot \mathrm{K}^{-1}\right], T$ - temperatura procesu $[\mathrm{K}]$, $w_{\text {cat }}$ - gęstość katalizatora $\left[\mathrm{g} \cdot \mathrm{m}^{-3}\right], A$ - stała Arrheniusa $\left[\mathrm{mol} \cdot \mathrm{min}^{-1} \cdot \mathrm{g}^{-1} \cdot \mathrm{atm}^{-(\mathrm{a}+\mathrm{b})}\right], E$ - energia aktywacji $\left[\mathrm{J} \cdot \mathrm{mol}^{-1}\right], a, b$ - rzędy reakcji [-].

$\mathrm{W}$ celu przygotowania modelu procesu oraz wyznaczenia opisu reakcji, niezbędne jest wyznaczenie empirycznych parametrów procesu: rzędów reakcji $a$ oraz $b$, energii aktywacji $E$ oraz współczynnika $A$.

\subsection{Uogólniona metoda najmniejszych kwadratów}

Metoda Najmniejszych Kwadratów jest jedną z metod przybliżonego rozwiązywania nadokreślonych układów równań. Nadokreślone układy równań charakteryzują się większą liczbą równań niż zmiennych. Szczegóły metody oraz jej wykorzystanie w problemach związanych z energetyką opisano w [7].

Uogólniona Metoda Najmniejszych Kwadratów (Generalized Least Squares - GLS) zakłada, że wszystkie zmienne występujące w modelu (zarówno wyniki pomiarów $\mathbf{u}$ jak i niewiadome $\mathbf{x}$ ) są traktowane $\mathrm{z}$ matematycznego puntu widzenia jako wyniki bezpośrednich pomiarów u. Dla wartości będących niewiadomymi przyjmuje się, że ich błędy $s_{k}$ są duże w porównaniu z błędami bezpośrednich pomiarów $s_{n}$. Metoda GLS zakłada minimalizację funkcji:

$$
\Phi(\mathbf{v}, \mathbf{y})=\sum_{k=1}^{\mathrm{K}}\left(\frac{v_{k}}{s_{k}}\right)^{2}+\sum_{n=1}^{\mathrm{N}}\left(\frac{y_{n}}{s_{n}}\right)^{2} \rightarrow \min
$$

przy jednoczesnym spełnieniu układu równań ograniczeń modelu. Wektory poprawek pomiarów oraz niewiadomych oznaczono jako $\mathbf{v}$ oraz $\mathbf{y}\left(\mathbf{V}_{\mathbf{B}}=[\mathbf{v}, \mathbf{y}]\right)$. Po linearyzacji równań modelu oraz zastosowaniu metody mnożników Lagrange'a otrzymuje się następujące rozwiązanie:

$$
\mathbf{V}_{\mathbf{B}}=\mathbf{C}_{\mathbf{B}} \mathbf{A}_{\mathbf{B}}^{\mathrm{T}} \mathbf{F}_{\mathbf{B}}^{-1} \mathbf{W}_{\mathbf{B}} \text {, gdzie } \mathbf{F}_{\mathbf{B}}=\mathbf{A}_{\mathbf{B}} \mathbf{C}_{\mathbf{B}} \mathbf{A}_{\mathbf{B}}^{\mathrm{T}}
$$

gdzie $\mathbf{C}_{\mathbf{B}}$ - macierz kowariancji a priori, $\mathbf{A}_{\mathbf{B}}$ - blokowa macierz Jackobi'ego, $\mathbf{W}_{\mathbf{B}}$ - wektor residuów równań. Macierz kowariancji po procesie uzgadniania $\mathbf{C}_{\mathbf{V B}}$, definiująca jakość modelu:

$$
\mathbf{C}_{\mathrm{VB}}=\mathbf{C}_{\mathrm{B}}-\mathbf{C}_{\mathrm{B}} \mathbf{A}_{\mathrm{B}}^{\mathrm{T}} \mathbf{F}_{\mathrm{B}}^{-1} \mathbf{A}_{\mathrm{B}} \mathbf{C}_{\mathrm{B}}=\left[\begin{array}{cc}
\mathbf{C}_{\mathrm{U}} & \mathbf{C}_{\mathrm{UX}} \\
\mathbf{C}_{\mathrm{UX}}^{\mathrm{T}} & \mathbf{C}_{\mathbf{X}}
\end{array}\right]
$$

By wykorzystać algorytm GLS konieczne jest zdefiniowanie zbioru równań ograniczeń, wektora zmiennych zawierającego parametry mierzone oraz niewiadome, a także macierzy kowariancji a priori, która jest określona przez niepewności charakteryzujące poszczególne pomiary bezpośrednie oraz założone błędy niewiadomych. Preliminarna inicjalizacja wartości niewiadomych 
następuje na podstawie przeprowadzonej wstępnej analizy procesu. Następnie algorytm rozpoczyna iteracyjne obliczenia, mające na celu spełnienie warunku zbieżności: linearyzację równań ograniczeń poprzez obliczenie macierzy Jacobi'ego oraz obliczenie wektorów poprawek $\mathbf{V}_{\mathbf{B}}$ oraz macierzy kowariancji $a$ posteriori $\mathbf{C}_{\mathbf{V B}}$.

\section{Badania eksperymentalne oraz wstępna analiza}

W badaniach doświadczalnych wykorzystano 0.3 [g] próbkę katalizatora niklowego (Ni/YSZ 60:40\%vol). Cermet niklowy został wybrany ze względu na możliwość wykorzystania w anodach wysokotemperaturowych ogniw paliwowych typu SOFC [2]. Ponadto, jako popularny materiał katalityczny reakcji reformingu [4], zapewnia on możliwość szerokich analiz porównawczych z danymi literaturowymi oraz ewaluację różnych modeli procesu.

Schemat układu pomiarowego przedstawiono na Rys. 1. Do reaktora dostarczano wodę, azot oraz metan, natomiast skład osuszonych spalin (ułamki molowe $\mathrm{CH}_{4}, \mathrm{H}_{2}, \mathrm{~N}_{2}, \mathrm{CO}$ oraz $\mathrm{CO}_{2}$ ) badano metodą chromatografii gazowej.

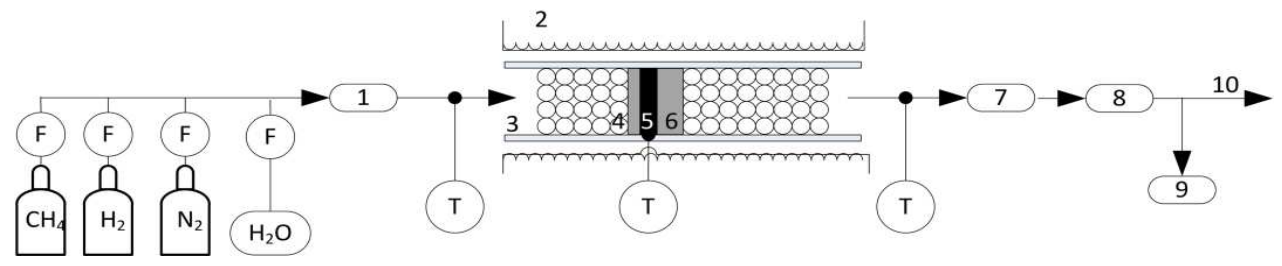

Rys. 1. Schemat układu pomiarowego: 1- podgrzewacz/parownik, 2 - piec, 3 - reaktor, 4 - tlenek glinu, 5 - katalizator, 6 - wełna, 7 - pogrzewacz/skraplacz, 8 - separator pary, 9 - chromatograf gazowy, 10 - spaliny, T - termopara, F - przepływomierz masowy

Fig. 1. Schema of the experimental set-up: 1 - evaporator/preheater, 2 - furnace, 3 - reformer, 4 alumina balls, 5 - catalyst, 6 - wool, 7 - afterheater/condenser, 8 - gas-liquid separator, 9 - gas chromatograph, 10 - exhaust, $\mathrm{T}$ - thermocouples, $\mathrm{F}$ - mass flow controller

Wartości inicjalizujące parametrów dla algorytmu GLS wyznaczono przez przeprowadzenie wstępnej analizy procesu według metodologii zaproponowanej przez Brusa i in. [2]. Wyniki poszczególnych etapów obliczeń: analizy odchylenia standardowego oraz wykresu Arrheniusa, pokazane na Rys. 2 posłużyły do wyznaczenia wstępnej formy równania kinetyki procesu:

$$
R_{s t}=w_{c a t} 7.37 \exp \left(-\frac{4.7 \cdot 10^{4}}{R T}\right) p_{\mathrm{CH}_{4}}{ }^{0.363} p_{\mathrm{H}_{2} \mathrm{O}}{ }^{0.137}
$$

gdzie: $w_{c a t}$ - waga katalizatora $[\mathrm{g}], R=8.314\left[\mathrm{~J} \mathrm{~mol}^{-1} \mathrm{~K}^{-1}\right]$ - uniwersalna stała gazowa, $T$ - temperatura [K], $p_{\mathrm{CH} 4} \mathrm{i} p_{\mathrm{H} 2 \mathrm{O}}$ - ciśnienia parcjalne $\mathrm{CH}_{4} \mathrm{i} \mathrm{H}_{2} \mathrm{O}$ [atm]. 

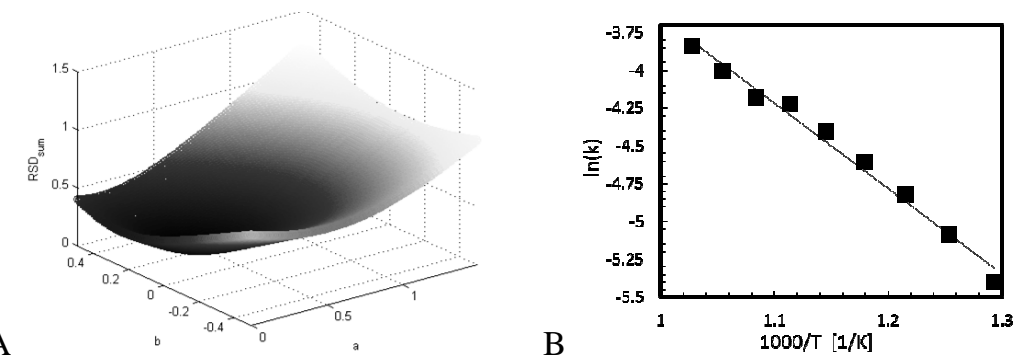

Rys. 2. A) Wyznaczenie współczynników rzędu reakcji oraz B) wykres Arrheniusa

Fig. 2. A) Calculation of reaction orders and B) Arrhenius plot

\section{Aplikacja Uogólnionej Metody Najmniejszych Kwadratów}

W celu wyznaczenia parametrów matematycznego opisu procesu reformingu metanu przy występującym nadmiarze informacji obarczonych błędami wykorzystano Uogólnioną Metodę Najmniejszych Kwadratów. Przedstawione przykłady pokazują zastosowania metody do wyznaczenia wartości poprawek wielkości mierzonych $\mathbf{v}$ i niewiadomych $\mathbf{y}$ a także do wyznaczenia macierzy kowariancji wyników po uzgadnianiu $\mathbf{C}_{\mathbf{V B}}$.

Analiza numeryczna zawiera warianty uwzględniające różną ilość równań warunków oraz różne ich typy. W modelach wykorzystano równania opisujące szybkość reakcji (6), liniową zależność Arheniusa (7), bilanse pierwiastków w systemie (8-11) oraz bilans wyjściowy (12):

$$
\begin{aligned}
& \frac{F_{\mathrm{CH}_{4}}{ }^{i(j)}-F_{\mathrm{CH}_{4}}{ }^{o(j)}}{w^{(j)}}-A \cdot \exp \left(\frac{-E \cdot 10^{3}}{R T^{(j)}}\right)\left(p_{\mathrm{CH}_{4}}{ }^{(j)}\right)^{a}\left(p_{\mathrm{H}_{2} \mathrm{O}}{ }^{(j)}\right)^{b}=0 \\
& \ln \left[A \cdot \exp \left(\frac{-E \cdot 10^{3}}{R T^{(j)}}\right)\right]-\left(-m_{\text {line }} \cdot \frac{1}{T^{(j)}}+n_{\text {line }}\right)=0 \\
& F_{\mathrm{CH}_{4}}{ }^{\mathrm{i}(j)}-\left(F_{\mathrm{CH}_{4}}{ }^{o(j)}+F_{\mathrm{CO}_{2}}{ }^{o(j)}+F_{\mathrm{CO}}{ }^{o(j)}\right)=0 \\
& 4 F_{\mathrm{CH}_{4}}{ }^{i(j)}+2 F_{\mathrm{H}_{2} \mathrm{O}}{ }^{i(j)}-\left(4 F_{\mathrm{CH}_{4}}{ }^{o(j)}+2 F_{\mathrm{H}_{2} \mathrm{O}}{ }^{o(j)}+2 F_{\mathrm{H}_{2}}{ }^{o(j)}\right)=0 \\
& F_{\mathrm{H}_{2} \mathrm{O}}{ }^{\mathrm{i}(j)}-\left(F_{\mathrm{CO}}{ }^{o(j)}+F_{\mathrm{CO}_{2}}{ }^{o(j)}+2 F_{\mathrm{H}_{2} \mathrm{O}}{ }^{o(j)}\right)=0 \\
& F_{\mathrm{N}_{2}}{ }^{\mathrm{i}(j)}-F_{\mathrm{N}_{2}}{ }^{\mathrm{o}(j)}=0 \\
& F_{\mathrm{ALL}}{ }^{o(j)}-\left(F_{\mathrm{CH}_{4}}{ }^{o(j)}+F_{\mathrm{H}_{2} \mathrm{O}}{ }^{o(j)}+F_{\mathrm{H}_{2}}{ }^{o(j)}+F_{\mathrm{CO}_{2}}{ }^{o(j)}+F_{\mathrm{CO}}{ }^{o(j)}\right)=0
\end{aligned}
$$


gdzie $F$ - przepływ molowy [mol s${ }^{-1}$ ], indeksy i oraz o - strumień wejściowy oraz wyjściowy, $m_{\text {line }}$ i $n_{\text {line }}$ - współczynniki prostej Arrheniusa [-].

Wszystkie z powyższych równań zostały wykorzystane do obliczeń każdego z pomiarów eksperymentalnych - indeks $j$ odnosi się do $j$-tego punktu pomiarowego. Opis matematyczny wymaga wprowadzenia dodatkowych niewiadomych definiujących prostą Arrheniusa oraz niemierzone przepływy pierwiastków (m.in. azotu). Wektor zmiennych zbudowano z wielkości mierzonych oraz niewiadomych inicjalizowanych na podstawie wstępnej analizy (Rozdział 2).

Tabela 1 przedstawia szczegóły pięciu modeli reformingu zaimplementowanych w algorytmie GLS. Kolejne przypadki modelowe zawierają zwiększoną liczbę równań ograniczeń. Przypadek referencyjny (Test 5) zawiera równania jednakowe z Testem 4 oraz zmniejszoną liczbę punktów pomiarowych.

Tabela 1. Opis przeprowadzonych testów wraz z liczbą zmiennych i równań

Table 1. Description of conducted tests and a number of variables and equations

\begin{tabular}{|c|c|c|c|c|c|c|c|c|}
\hline & 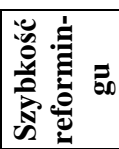 & 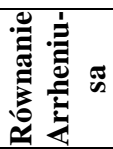 & 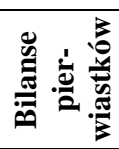 & 产 & 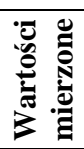 & 离 & 节 & 尝 \\
\hline Test 1 & $X$ & & & & 270 & 85 & 355 & 27 \\
\hline Test 2 & $X$ & $X$ & & & 270 & 87 & 355 & 54 \\
\hline Test 3 & $X$ & $\mathrm{X}$ & $\mathrm{X}$ & & 270 & 87 & 355 & 162 \\
\hline Test 4 & $X$ & $\mathrm{X}$ & $X$ & $\mathrm{X}$ & 270 & 87 & 355 & 189 \\
\hline Test 5 & $X$ & $\mathrm{X}$ & $X$ & $X$ & 200 & 66 & 266 & 140 \\
\hline
\end{tabular}

Tabela 2. Rezultaty - wartości parametrów a, b, A, E wraz z ich niepewnościami

Table 2. Results - values of parameters a, b, A, E with their uncertainties

\begin{tabular}{|c|c|c|c|c|}
\hline Test & $\mathbf{a}$ & $\mathbf{b}$ & $\mathbf{A}$ & $\mathbf{E}$ \\
\hline 1 & $0.10 \pm 0.48$ & $0.36 \pm 0.72$ & $6.06 \pm 34.1$ & $48.04 \pm 30.9$ \\
\hline 2 & $-0.02 \pm 0.47$ & $0.32 \pm 0.72$ & $-34.6 \pm 18.4$ & $8.06 \pm 12.6$ \\
\hline 3 & $0.25 \pm 0.06$ & $0.16 \pm 0.06$ & $8.43 \pm 3.5$ & $49.22 \pm 2.6$ \\
\hline 4 & $0.37 \pm 0.03$ & $0.05 \pm 0.04$ & $4.50 \pm 2.6$ & $44.81 \pm 1.99$ \\
\hline 5 & $0.39 \pm 0.04$ & $0.05 \pm 0.04$ & $5.07 \pm 2.9$ & $44.94 \pm 2.27$ \\
\hline
\end{tabular}

Zadaniem analizy było oszacowanie wartości parametrów określających szybkość badanego procesu: $a, b, A, E$. Ich wartości wraz z charakteryzującymi je niepewnościami zebrano w Tab. 2. Suma elementów diagonalnych macierzy kowariancji $\mathbf{C}_{\mathbf{V B}}$, przedstawiona na Rys. 3B oraz 3C, może służyć za miarę jakości uzyskanego rezultatu - czym mniejsza uzyskana wartość, tym model dokładniej opisuje proces. Na Rys. 3A pokazano wyznaczone w poszczególnych testach rzędy reakcji wraz z ich niepewnościami. Pokazano, że zwiększenie liczby równań modelowych, nakłada dodatkowe warunki, usztywniające uzyskane rezultaty. Szczególnie znaczące jest wymuszenie spełnienia równań 
bilansowych - powoduje to efektywne wykorzystanie wszystkich mierzonych wielkości, co zmniejsza niepewność końcowych rezultatów. Zgodnie z przewidywaniami, Test 5, analizujący zmniejszoną liczbę danych pomiarowych charakteryzuje się niewielkim pogorszeniem rezultatu względem Testu 4.

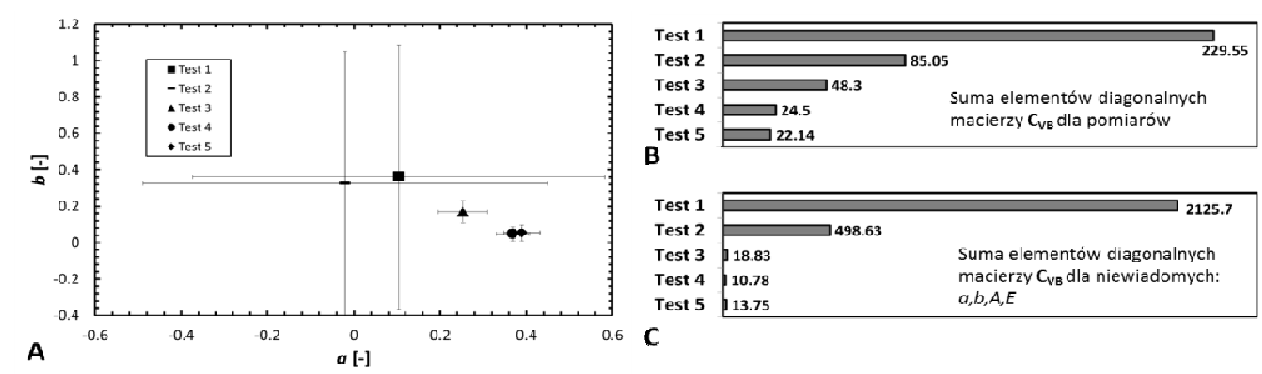

Kys. 3. A) Wyznaczone wartoścı parametrów a 1 b wraz z niepewnosciamı oraz suma elementow diagonalnych macierzy $\mathbf{C}_{\mathbf{V B}}$ dla: B) pomiarów i C) niewiadomych

Fig. 3. Calculated values of both $a$ and $b$ parameters with their uncertainties and sum of diagonal elements of $\mathbf{C}_{\mathbf{V B}}$ matrix for: B) measurements and $\mathbf{C}$ ) unknowns

\section{Wnioski}

W pracy przedstawiono analizę procesu reformingu parowego metanu za pomocą Uogólnionej Metody Najmniejszych Kwadratów. Metoda ta jest stosowana, gdy model numeryczny zawiera większą niż niezbędna dla uzyskania jednoznacznego rozwiązania ilość pomiarów, jednak uzyskane wyniki pomiarowe są obarczone błędami eksperymentalnymi. W takiej sytuacji możliwe jest uzyskanie skończonego zbioru rozwiązań prawdopodobnych. Metoda GLS pozwala na wybranie rozwiązania najbardziej prawdopodobnego oraz wyznaczenie określającej je niedokładności. Algorytm GLS zapewnia ponadto poprawę dokładności oszacowania wielkości mierzonych eksperymentalnie.

$\mathrm{W}$ pracy omówiono przeprowadzone badania eksperymentalne oraz ich wstępną analizę, którą następnie wykorzystano do inicjalizacji wektorów zmiennych w metodzie GLS. Przedstawiono ponadto wpływ wyboru równań modelowych na jakość uzyskiwanych rezultatów oraz wybrano zbór równań ograniczeń najlepiej opisujące badany przypadek. Najbardziej precyzyjny model składał się z równań określających kinetykę badanej reakcji, prostoliniową zależność Arrheniusa, bilanse pierwiastków w strumieniach wejściowym i wyjściowym oraz bilanse udziałów molowych w strumieniu wyjściowym. Dokładny opis reakcji reformingu metanu, który można uzyskać dzięki zastosowaniu metody GLS, jest kluczowy z punktu widzenia modelowania i optymalizacji systemów ogniw paliwowych SOFC.

\section{Literatura}

[1] Achenbach E., Riensche E.: Methane/steam reforming kinetics for solid oxide fuel cells, J. Power Sources, 52 (1994) 283-288. 
[2] Brus G., Komatsu Y., Kimijima S., Szmyd J.S.: An Analysis of Biogas Reforming Process on Ni/YSZ and Ni/SDC Catalysts, Int. J. Thermodyn., 15 (2012) 43-51.

[3] Komatsu Y., Kimijima S., Szmyd J.S.: Numerical analysis on dynamic behavior of solid oxide fuel cell with power output control scheme, J. Power Sources, 223 (2013) 232-245.

[4] Mogensen D., Grunwaldt J.-D., Hendriksen P.V., Dam-Johansen K., Nielsen J.U.: Internal steam reforming in solid oxide fuel cells: Status and opportunities of kinetic studies and their impact on modelling, J. Power Sources. 196 (2011) 25-38.

[5] Odegard R., Johnsen E., Karoliussen H.: Methane reforming on Ni/Zirconia SOFC anodes, Solid Oxide Fuel Cells IV, The Electrochemical Society, Pennington, New York 1995, pp. 810-819.

[6] Sciazko A., Komatsu Y., Brus G., Kimijima S.,. Szmyd J.S.: A novel approach to the experimental study on methane/steam reforming kinetics using the Orthogonal Least Squares method, J. Power Sources, 262 (2014) 245-254.

[7] Szargut J.: Rachunek wyrównawczy w technice cieplnej, PAN, Komisja Energetyki, Wrocław 1984.

Prace byty finansowane przez Narodowe Centrum Badań i Rozwoju (Projekt HTRPL, Kontrakt nr SP/J/1/166183/12) oraz Precise Measurement Technology Promotion Foundation of Japan.

\title{
METHANE STEAM REFORMING PROCESS ANALYSIS WITH GERERALIZED LEAST SQUARES ALGORITHM
}

\begin{abstract}
S u m m a r y
Mathematical model of the physical phenomena contains the uncertainties resulted from the inaccuracy of the measurements, assumed values of parameters and model simplifications. The article presents the experimental and numerical analysis of methane steam reforming process with Generalized Least Squares Method (GLS). Published in the literature equations about kinetics of reforming process are different and they do not contain the uncertainty analysis of the obtained results. The GLS algorithm is adopted to select the most probable values of reforming kinetics parameters and to objectively validate proposed mathematical models. The numerical analysis was conducted on the basis of the experimental measurements of $0.3 \mathrm{~g} \mathrm{Ni} / Y S Z 60: 40 \mathrm{vol}$ catalyst sample. It was proven that GLS method is useful in securing higher accuracy of measured variables, finding the most probable values of unknowns and simultaneously determining the uncertainty coupled with all the variables in the system.
\end{abstract}

Keywords: Ni/YSZ catalyst, steam methane reforming, analysis of measuring errors

DOI: $10.7862 / \mathrm{rm} .2014 .11$ 